\title{
Obama's Ethics Agenda: The Challenge of Coordinated Change
}

\section{Citation}

Thompson, Dennis F. 2009. Obama's ethics agenda: The challenge of coordinated change. The Forum 7(1), Article 8.

\section{Published Version}

http://dx.doi.org/10.2202/1540-8884.1290

\section{Permanent link}

http://nrs.harvard.edu/urn-3:HUL.InstRepos:4728510

\section{Terms of Use}

This article was downloaded from Harvard University's DASH repository, and is made available under the terms and conditions applicable to Other Posted Material, as set forth at http:// nrs.harvard.edu/urn-3:HUL.InstRepos:dash.current.terms-of-use\#LAA

\section{Share Your Story}

The Harvard community has made this article openly available.

Please share how this access benefits you. Submit a story.

\section{Accessibility}




\title{
The Forum
}

Volume 7, Issue 1

2009

Article 8

The Obama Administration: Setting Up a Government

\section{Obama's Ethics Agenda: The Challenge of Coordinated Change}

\author{
Dennis F. Thompson*
}

*Harvard University, thomps2@ fas.harvard.edu

Copyright (c)2009 The Berkeley Electronic Press. All rights reserved. 


\title{
Obama's Ethics Agenda: The Challenge of Coordinated Change*
}

\author{
Dennis F. Thompson
}

\begin{abstract}
Obama's "ethics agenda" is the most ambitious ever set out by a new administration. It promises a tougher approach not only to the usual problems such as conflict of interest and the revolving door, but also to broader challenges such as political influence on career officials and lack of transparency in government. The goals of the agenda are a step forward insofar as they focus more on improving the democratic process than disciplining political miscreants. But the means relied on to carry out the goals are less impressive. They perpetuate a major deficiency of the current ethics regime-its disjointedness, which undermines the transparency and accountability necessary for a robust democracy. What is needed is a coordinated approach, led from the White House itself, that takes a more comprehensive view of ethics regulation throughout the government.
\end{abstract}

KEYWORDS: ethics, presidency, administration, federal government, reform

* Dennis F. Thompson is the Alfred North Whitehead Professor of Political Philosophy at Harvard University, and the founding director of the university-wide Edmond J. Safra Center for Ethics. Thompson's recent books include: Restoring Responsibility: Ethics in Government, Business, and Healthcare; Just Elections: Creating a Fair Electoral Process in the United States; Ethics in Congress: From Individual to Institutional Corruption; and Political Ethics and Public Office. He co-authored (with Amy Gutmann) Why Deliberative Democracy? and Democracy and Disagreement. 
Every president in recent years has sooner or later found his administration disrupted for some period of time by major, often unexpected and sometimes unnecessary, episodes of ethical controversy. Early in his administration, Bill Clinton proposed tough post-employment standards, and promised a new regime of integrity in Washington. Then followed the travails of Whitewater, Monica Lewinsky, Henry Cisneros, and Mike Espy among others. Few of the Clinton administration scandals led to indictments, let alone convictions. But the largely unwarranted sensationalism of several of the scandals and the cumulative effect of all distracted the administration and depleted its political capital.

On his second day in office, George W. Bush told his staff: "[W] must remember the high standards that come with high office. ... I expect every member of this administration to stay well within the boundaries that define legal and ethical conduct. This means avoiding even the appearance of problems."1 By the end of his second term, more than a dozen of his appointees had been found guilty of serious offenses or forced to resign as a result of ethics scandals. The damage extended to at least nine agencies and departments. ${ }^{2}$

Obama will certainly not suffer a Lewinsky-style disgrace, and almost as certainly nothing like the scandal-ridden years of Bush's second term. He faces a special challenge in this area nevertheless. He has made ethics a signature issue. Yet he abandoned public financing in his campaign - rightly observing that the system was "broken," but without suggesting much about how to fix it. The chair of his vice presidential search and his nominee for Secretary of Commerce had to withdraw because of conflict of interest problems. His Secretary of State's spouse heads a Foundation that creates potential conflicts. His nominees for Treasury, Health and Human Services, and the new position of chief performance officer ran into trouble for failing to pay taxes in the past.

The unprecedented euphoria that greeted his arrival will carry his administration through any controversies that might arise in the first 100 days (and probably beyond). His nominees have already escaped the severe censure and forced withdrawals that some of those in previous administrations have suffered for lesser transgressions. But as he makes the hard choices that the economy, national security, health care, and other issues require, and more than occasionally fails to locate that common ground he admirably seeks, he will need to call on large reservoirs of personal trust and public confidence. Whether those

\footnotetext{
${ }^{1}$ He added: "My White House counsel, Al Gonzalez, is my point man on these issues. If you have even a hint of ethical doubt, I urge you to talk to Al." [President Bush's Remarks at the SwearingIn Ceremony for New White House Staff, January 22, 2001. http://transcripts.cnn.com/ TRANSCRIPTS.0101/22/se.02.html.]

${ }^{2}$ Offenders held high positions in Interior, Justice, Homeland Security, Housing and Urban Development, Labor, the General Services Administration, the Office of Management and Budget, the Food and Drug Administration, and the Office of the Vice President.
} 
reservoirs remain sufficient depends in large part on maintaining a robust regime of ethics.

Even without this special challenge, the ethics regime in Washington needs attention. Its integrity stands in question, partly because of the ethical lapses of the Bush administration during the past eight years. More generally, government ethics needs attention because it has not received a comprehensive review either in Congress or the White House since at least the Ethics Reform Act of $1989 .^{3}$ Such a review would also provide the opportunity to consolidate and write into law the ethics rules now established by executive orders, which come and go with changing administrations.

Some of the scandals in previous administrations could have been prevented, and those that could not have been, including those that were exaggerated by the press, could have been handled more effectively. But more rigorous vetting procedures and more skillful political responses, useful though they may be, are not the answer. Presidential nominees are already subjected to extensive reviews by the White House Ethics Office, the Clearance Counsel, and the FBI before their names are sent to the Senate. The ethics effort has been overly focused on individuals - trying to make sure that they comply with the rules, and responding when they do not. It has given less attention to the institutional structures in which individuals act - failing to analyze sufficiently the patterns of conduct, systematic incentives, and general practices in which ethics regulation takes place.

What is needed is institutional reform that takes a more comprehensive view and adopts a more coordinated approach. More focus on developing coherent institutional policy than on responding to actual and potential individual culpability would better serve both the administration and the democratic process. Obama's ethics agenda moves in this direction, though not yet far enough. ${ }^{4}$

\footnotetext{
${ }^{3}$ Public Law No. 101-194, Ethics in Government Act of 1978 (P.L. 95-521, 92 Stat. 1824) amended by the Ethics Reform Act of 1989 and the Honest Leadership and Open Government Act of 20075 U.S.C.A. App. $4 \S 101$ et seq. and 5 U.S.C. $\S 7353$; 5 C.F.R. $\S 2635$, and 41 C.F.R. $\S \S$ 301-1 and 304-1. The Ethics in Government Act was enacted under the first Bush, whose administration, perhaps not incidentally, can boast a cleaner ethics record than most.

${ }^{4}$ The agenda, featured on the campaign website as "The Obama-Biden Plan," was transferred to the White House website at noon on January 20, and then almost immediately replaced with this notice: "The ethics section is currently being revised to reflect President Obama's Executive Order concerning Ethics Commitments by Executive Branch Personnel, issued on January 21, 2009. Please check back soon." The references to the "original agenda" that follow are to this document at http://change.gov/agenda/ ethics_agenda. The new Executive Order is available online at whitehouse.gov.
} 


\section{Skepticism about Government Ethics}

In one sense, ethics should not have a high priority, given all the other pressing issues. It is not as urgent as the economy or the war in Afghanistan. That is partly why it is at risk of neglect. "Please check back soon" could easily become the agenda's permanent label. But in another sense, ethics is the most important issue because the efforts to deal with all of the others can be disrupted if it is neglected. Like a low-grade virus that quietly wears down one's strength, and then erupts into a major infection at unpredictable and unwelcome moments, ethics lapses can steadily sap the strength of the body politic, and leave its leaders vulnerable at the most inopportune times.

Government ethics is often neglected not just because there are other more pressing issues, but also because there are some persisting conceptions of its purpose. Ethics regulation is intended not mainly to prevent crimes (that is what the law is for), and not merely to promote favorable public relations (that is what political operatives are for). Its main purpose is to create and sustain confidence in government - to give the public reasonable assurance that public officials are making decisions on the merits for the right reasons. To be sure, ethics regulation is also supposed to create incentives to make decisions on the merits, but for that purpose other methods are available and more effective - making sure that honest and qualified people are appointed, for a start. Ethics regulation assumes that most officials are honest. It would not be sustainable otherwise. The rules are to provide reassurance, not to instigate recriminations. The failure to appreciate this core purpose is the source of some of the most common resistance to ethics regulation.

Some critics acknowledge this purpose of ethics regulation in principle but question its value in practice. The costs are not worth the benefits, they say. The most commonly mentioned cost is the presumed negative effect on recruitment. The regulations are burdensome and invasive, and consequently discourage talented people from serving in government. There is surprisingly little systematic evidence about this supposed effect. The author of the most extensive recent discussion claiming that the effects are negative acknowledges the "absence of consistent data on the percentage of people invited to join an administration who decline to do so and the reasons they cite for declining. $" 5$ He relies largely on comments from senior officials in previous administrations who had responsibility for personnel appointments. The evidence consists of statements from these officials that candidates, usually unnamed, withdrew from consideration because of the prospect of dealing with the regulations.

\footnotetext{
${ }^{5}$ G. Calvin Mackenzie, Scandal Proof: Do Ethics Laws Make Government Ethical? (Washington, DC: Brookings Institution Press, 2002), pp. 125-36.
} 
In the absence of more systematic evidence, we do not know in how many cases the complaints about the regulations are the primary reason for declining to be considered or refusing offers of appointment. Candidates, especially those in lucrative private-sector positions, have plenty of other reasons to turn down public office. For some candidates, the regulatory burden may be a convenient excuse, more respectable or at least easier to explain than their real reasons. Finally, to the extent that the regulations are a disincentive, we do not know what exactly is discouraging candidates: the prospect of filling out the forms, disclosing private matters, having to divest some holdings, or accepting restrictions on postemployment lobbying.

Some of these burdens have been made less onerous in recent years; for example, when nominees divest, they are given a certificate of divestiture allowing them to defer capital gains tax (a device that enables some nominees to actually benefit). Other burdens could be eased by changes in the regulations, but some are serving their purpose in discouraging people who should be discouraged from government service. Some conflicts should in fact be disqualifying. Furthermore, candidates who do not sufficiently appreciate the importance of maintaining public confidence may not be the most suitable appointees. In any case, it would be desirable to conduct systematic empirical studies of the effects of ethics regulation on recruitment, a project that an administration committed to pragmatic policy making should favor. But given the surplus of talented individuals eager to serve in the new administration, the concern about the difficulties of recruitment are not likely to seem pressing. An inspiring leader evidently can induce many able people to discount the inconveniences of the ethical scrutiny.

Another objection about the value of ethics regulation is that, even if the costs are less than critics believe, the benefits are less than the proponents of regulation claim. The "vast expansion of ethics regulation," it is said, has not done much if any good. ${ }^{6}$ The rules seem to have become stricter, but ethical conduct and trust in government have not improved, and may have worsened. To be sure, trust in government has declined, but whether ethics regulation contributed to the decline or prevented it from becoming worse has not been shown. The conclusion would be hard to establish either way because the effects of ethics regulation are likely to be overwhelmed by the consequences of deception and other misconduct by high officials in recent years. Also, any positive effects on trust, if they exist, may not show up directly in public opinion surveys; they are more likely to work indirectly through the initial influence on opinion leaders. It would be useful to try to analyze which kinds of regulations opinion leaders and other citizens think are more or less important, and what kinds of misconduct they regard as more or less

\footnotetext{
${ }^{6}$ Mackenzie, pp. 86, 107-14.
} 
serious. But even without this analysis or other systematic evidence, several observations can be made that cast doubt on this argument that regulation is not beneficial.

First, the rules for the executive branch have not in fact become significantly stricter in the period of the greatest decline in trust. With the exception of postemployment restrictions, the federal ethics standards have been "basically the same" as those adopted by the Johnson administration more than 40 years ago (though the administrative apparatus and paperwork have obviously expanded). ${ }^{7}$

Second, the impression that unethical behavior has increased or at least not declined may be a consequence of the regulatory regime itself, which has raised the salience of ethics issues. The impression may also be the result of greater disagreement about ethical standards as more people from diverse backgrounds and with different values come to play a larger role in politics. In both these respects, the resulting ethical controversy should be welcomed. It is more healthy than ethical silence in democratic politics even if the immediate effect is an increase in distrust.

Finally, whether or not ethics regulation has a minimal effect on trust, it is required by the principles of democracy. There is little evidence that campaign debates change many people's minds, yet we believe that candidates should engage in them. Similarly, holding public officials to high standards of ethics is part of what makes our government a democracy: officials should be accountable for making decisions for the right reasons. Ethics regulation supplements elections and other imperfect devices of accountability.

Although more systematic empirical study of the effects of ethics regulation would be valuable, reform of the current regime does not have to wait for further evidence. The Obama administration has correctly identified a number of areas that need attention. The process of trying to make changes is itself likely to generate more information about the strengths and weaknesses of various rules and policies. The officials who have run the ethics regime, those who have been subject to it, and independent outside experts constitute a rich source of accumulated knowledge in this area, which can be tapped as the reform efforts go forward.

Although the reforms may have to be incremental, they should be considered from a more comprehensive perspective than has prevailed in the past. The most serious deficiency of the current regime is its disjointedness: no one is responsible for considering the system of regulation as a whole, and consequently the standards and the procedures for administering them lack the consistency and transparency necessary to serve the aims of ethics regulation. Obama's reform

\footnotetext{
${ }^{7}$ Gregory S. Walden, On Best Behavior: The Clinton Administration and Ethics in Government (Indianapolis: Hudson Institute, 1996), pp. 61-62.
} 
proposals are admirable in many ways, but even they will fall short unless they are undertaken with a more coordinated approach embracing the whole ethics regime. To appreciate both the importance of his agenda and the need for such an approach, we can examine the most prominent proposals that the new administration has promised to address in its "ethics agenda," those that are intended to "free the executive branch from special interest influence," and "shine the light" on lobbying, contracts, regulatory discussions and other government business $^{8}$

\section{"Close the Revolving Door"}

When Bill Clinton came into the White House, he announced that he would impose the toughest ethics standards in history for his appointees. Senior officials could not lobby their former agencies for five years and could never lobby on behalf of foreign governments after they left office. ${ }^{9}$ But just before leaving office, he revoked the order, claiming it had served its purpose. Because the Republicans were taking over, his counsel said, Clinton appointees would not have many opportunities to influence their former agencies. (But then why would allowing the prohibition to stand have been such a heavy burden?) Clinton's revocation provided a convenient excuse for those in the incoming Bush administration who did not want to be bound by the stricter rule. Ethics regulation waned as ethics violations waxed.

Obama's executive order, issued on his first day in office, revives the Clinton provisions but with some significant changes - most but not all in the direction of stricter regulation. ${ }^{10}$ The five-year ban on influencing one's former agency is reduced to two (though still a year longer than the statutory limit under which the Bush administration operated for all but very senior officials). Also, Clinton's order banned all senior officials from trying to influence any executive agency on matters in which they had personal involvement. Under Obama's order, only officials who become registered lobbyists are subject to that broad a ban, and then

\footnotetext{
${ }^{8}$ See http://change.gov/agenda/ethics. The agenda is divided into five sections: "Shine the Light on Washington Lobbying," "Shine the Light on Federal Contracts, Tax Breaks and Earmarks," "Bring Americans Back into their Government," "Free the Executive Branch from Special Interests, and "Spend Taxpayer Money Wisely." In each section, there are several proposals intended to promote the stated goal, though none is as specific as an executive order or legislative bill.

${ }^{9}$ Executive Order 12834 of January 20, 1993, "Ethics Commitments by Executive Branch Appointees." Notice also that the prohibition applies not only to registered lobbyists, but to anyone whose job involves trying to influence the government on a regular basis. This is broader than the scope of the rules that the Bush and Obama administrations and Congress adopted.

10 "Executive Order - Ethics Commitments by Executive Branch Personnel," January 21, 2009. http://www.whitehouse.gov/the_press_office/ExecutiveOrder-EthicsCommitments/.
} 
only for the remainder of the administration. But Obama's rule does treat lobbyists more strictly: they may not lobby any "covered Executive Branch official" (which includes the White House senior staff and most other high level officials). In addition, Obama's appointees must look a gift lobbyist in the mouth. The current law already bans gifts of more than $\$ 20$ in value but now officials may not accept "any gratuity, favor, discount, entertainment, hospitality, loan, forbearance, or other item having monetary value."11 The exception remains for gifts from personal friends - of whom Jack Abramoff evidently had many.

The most significant change - and it is a definite advance - is that Obama's order looks to the past as well as the future. Where officials enter the revolving door from is now as important as where they go when they exit. For the first two years of their service, political appointees may not participate in a "particular matter" involving "specific parties" that is directly and substantially related to their former employer or clients. The language (which is the same as the postemployment restriction) is more limited than it might appear. It does not cover that vast range of government business that affects an entire industry rather than a single party, but it is a step forward as far as it goes. The rule is stricter for former lobbyists: they may not participate in "any particular matter" on which they lobbied, or any issue area in which the matter falls, and may not even work in an agency that they lobbied. ${ }^{12}$

The new rule is so tough that several of Obama's nominees - notably, Deputy Secretary of Defense William Lynn, who had been a lobbyist for the defense contractor Raytheon - needed to request waivers or recuse themselves from whole areas of policy in their departments. It remains to be seen whether the rule is sustainable if the waivers and recusals become common. But the rule is a significant expansion of the scope of the revolving-door restrictions as far as lobbying is concerned.

Why is it important to try to cover both entering and exiting? The limits on what officials do after they leave is partly intended to minimize doubts about whether their decisions while in office are influenced by their prospects for employment later. But these prospects are speculative and usually not connected with specific persons or companies. As necessary as the post-employment

\footnotetext{
11 This definition of a gift follows the existing legislation: 5 USC $101 \mathrm{sec} .101$. The gift restrictions are another area that would benefit from a comprehensive review that aimed to simplify and rationalize the rules and exceptions. Some (such as meals) are probably overregulated, and others (such as travel sponsored by outside groups), under-regulated. The gifts that many officials value most of all — campaign contributions - do not fall under the definition at all.

${ }^{12}$ This is not quite as restrictive as the New York Times editorial board assumed: "[N]o one may serve in the Obama administration if he or she lobbied an executive agency in the preceding two years." (New York Times Editorial Board, "The President Orders Transparency," New York Times, January 23, 2009.)
} 
restriction is, then, the pre-employment rule may be more important. Newly arriving officials bring their connections with them, and their connections are not only recent but specific. The risks here are more definite and the doubts more reasonable. Some former ethics officials believe that the entering conflicts are where the most serious damage is done. In the climate of the current "bail-out" economy, the restrictions on appointees to positions who are to have major responsibility for financial matters have become more important than ever.

But the fundamental reason for imposing restrictions on the revolving door in both directions is often lost in the preoccupation with particular individuals and particular decisions. The basic justification for the restrictions is based on the principle that the democratic process should be open on fair terms to all citizens. Access cannot ever be strictly equal, but it should not overwhelmingly favor those who make their living in Washington politics along with the special interests they represent. It is a matter of proportion. The growth of the lobbying industry and the influence of money in politics have shifted the balance toward a system that begins to look more plutocratic than democratic.

This disproportionate access is a general problem in our system. But the revolving door between government and lobbying firms makes it worse. Lobbyists serve an important and valuable function in a democracy, but when their ranks are filled with people coming from government or waiting to return, and reaping outsized financial rewards, their activities undermine the very practice of democratic representation. The revolving door becomes a perversion of the classical democratic principle of rotation in office. Instead of citizens ruling and being ruled in turn, politicians are lobbying and being lobbied in turn.

The problem is more structural than individual. The individual behavior may not even be unethical, but the collective result over time is undemocratic. The preand post-employment rules seek to close, or at least slow down, a revolving door that sustains a culture of coziness, an inside-the-beltway ethos and network of connections that make access far easier for insiders than ordinary citizens. That culture also creates barriers that discourage newcomers and new ideas, stifling the process of challenge and renewal on which a robust democracy depends. Money comes to count more than merit. Protecting the integrity of the democratic process, more than restraining the greed of the individual politicians, is at the core of political ethics. That goal should also guide the assessment of revolving door restrictions.

\section{"Free Career Officials from the Influence of Politics"}

In the original agenda, this goal was to be achieved by asking all new hires at the agencies to sign a statement declaring that they were not offered their job "solely on the basis of political affiliation or contribution." Perhaps because the drafters 
realized that career officials are rarely hired solely on this basis (or if they are, proving it is almost impossible), Obama's executive order puts the statement more positively, and shifts the burden to the officials who are doing the hiring rather than those being hired. The new pledge is: "[A]ny hiring or other employment decisions I make will be based on the candidate's qualifications, competence, and experience." The commitment is admirable, but both its end and means are underspecified.

The pledge permits political considerations not only to play a role in hiring decisions (which is justifiable) but also to play a greater role than qualifications (which is questionable). Part of the aim should be to discourage hiring less qualified candidates in preference to significantly more qualified candidates, and to prevent hiring qualified candidates without a good-faith search for the most qualified. Moreover, hiring is not the only concern. Firing for political reasons is even more insidious, because of the chilling effect it can have on other officials. Senior officials should be held accountable for making sure their subordinates do not conduct the kind of purges that Justice Department officials carried out in dismissing seven U.S. attorneys in 2006.

Less drastic and more subtle forms of political pressure are also troublesome. For example, political appointees in Bush's Interior Department are alleged to have "compromised the scientific basis" of decisions by exerting improper influence on career professionals administering the Endangered Species Act. ${ }^{13}$ Finally, the less well-known practice of "burrowing" - the transfer of political appointees to the career services - can be abused for political purposes, and even when well-intentioned, can undermine the integrity and morale of the career services. ${ }^{14}$ Although burrowing occurs most often at the end of an administration, Obama's team may have an opportunity to reverse some of these appointments and in any case can take steps to limit this practice in the future.

As the means of protecting career officials from political influence, signing a pledge seems a rather tepid technique. Perhaps the new administration does not think that much more needs to be done here than to reaffirm the commitment to a professional civil service. It is true that the most egregious types of political interference are covered by federal law and civil service regulations. The Hatch Act prohibits some kinds of political activity and discourages (at least indirectly)

\footnotetext{
${ }^{13}$ Statement of Robin M. Nazzaro, Director Natural Resources and Environment, "Testimony before the Committee on Natural Resources, House of Representatives, Endangered Species Act Decision Making," U.S. Government Accountability Office, May 21, 2008.

${ }^{14}$ Barbara L. Schwemle, "Federal Personnel: Conversion of Employees from Appointed (Noncareer) Positions to Career Positions in the Executive Branch," Congressional Research Service, October 14, 2008.
} 
political pressure by political appointees. ${ }^{15}$ Personnel actions must respect the nine merit principles and avoid the twelve prohibited personnel practices specified in the U.S. Code. ${ }^{16}$ Department and agency heads also must follow civil service rules administered by the Office of Personnel Management.

Missing from the pledge is any sense that senior officials (including those in the White House) should be responsible for making sure that their subordinates respect the independence of career officials. Also missing is any effective means of enforcement. The Office of Government Ethics in consultation with the Office of Personnel Management is charged with making sure the pledge is honored, but left entirely unclear is how these officials can determine when a personnel decision is based more on political connections than on professional qualifications. Whistleblowers (who are to be better protected under Obama's ethics proposals) may help expose the most egregious abuses. But without periodic review at a high level, patterns of routine abuses and the cumulative effects of many minor lapses throughout an administration are less likely to be noticed and addressed.

The administration itself has a strong interest in making sure that all appointees are highly qualified, but it also has a legitimate interest in making sure that its political agenda is carried out. There may be a fine line between legitimate and illegitimate political considerations. The Attorney General is justified in choosing and retaining only U.S. attorneys who support the president's priorities in criminal justice, but not justified in choosing and retaining only attorneys who decline to make decisions about prosecution on the basis of partisan politics. A department is not always in the best position to be the sole and final arbiter of these judgments. Without the capacity for periodic review of practices and policies by ethics officials directly responsible to the president, an administration's effort to respect the demands of both professionalism and politics is left entirely in the hands of the department and agencies, none of which are well placed to take a comprehensive view.

\section{"Reform the Political Appointee Process"}

Political appointees are, as the name implies, properly appointed partly on the basis of political considerations. The Obama administration makes no attempt in its agenda to suggest that political affiliation should play no role. The president was elected to carry out a program, and he should be able to command the loyalty of the top officials in his administration. Of the some 8,000 positions listed in the

155 U.S.C. $\S \S 7321-7326$. However, the Act's prohibition of political activity on government property during working hours does not apply directly to Cabinet officers, senior political appointees and White House staff.

${ }^{16} 5$ U.S.C. $\$ \$ 2301(b)$ and 2302 (b). 
so called Plum Book, the White House probably appoints fewer than 2,000 of those. If the past is any guide, some will go to people who worked in the campaign, served in the previous Democratic administration, or have connections to prominent Democratic politicians on the Hill and in the states. That is to be expected, and indeed warranted: loyalty and trust are essential ingredients for any administration. But so is competence, and the challenge is to make sure that it gets at least as much weight. Obama's agenda mentions the most notorious case where it did not: "no one would pretend that FEMA Director Michael Brown was qualified to head the agency, and the result was a disaster for the people of the Gulf Coast."

But then all that follows in the agenda is this vague declaration: "[E]very official will have to rise to the standard of proven excellence in the agency's mission." No doubt the new administration is confident it will not make the "heck of a job Brownie" mistake, and so far the quality of appointments bears out its confidence. But the process is as important as the results, and it is not as transparent as it should be. Most citizens and even the press cannot keep track of or find out much about the many mid- and lower-level appointments. Perhaps they can infer from the way that high-level appointments are made that the other, less visible ones are being made in the same way. But a better process would make both less obscure.

At a minimum, the availability of the positions should be posted in advance, with a stated deadline for applying. The Plum Book is generally out of date by the time it is printed: online postings, searchable and timely, would be more useful. (In exceptional cases, to avoid disrupting the work of the agency, a high-level resignation may have to be kept confidential until a replacement is found.) It is not practicable (or desirable) to publicize the names of the leading candidates for a job (though in effect that is what often happens with high-level positions as a result of leaks). But for all appointments that require Senate confirmation, a brief comment period could be formally required after the nomination is announced but before the Senate committee takes up the nomination. Any comments would have to be made in writing and not anonymously. It would be better for all concerned if any disqualifying objections came out before rather than after the appointment is made.

\section{"Enforce Executive Branch Ethics"}

The main instrument for promoting this part of the agenda is the Office of Government Ethics. Originally part of the Office of Personnel Management, the OGE became an independent agency in 1989. Its staff is strictly professional; the only political appointee is the director. Its main functions are to review the financial disclosure forms of political appointees, provide ethics training and 
advice, and oversee the administration of ethics rules by other officials in all federal agencies. There are nearly 130 "designated agency ethics officials" scattered throughout the executive branch. In addition, more than 6,200 other officials have some formal responsibility for ethics.

Despite its name and independent status, the OGE is not an all-inclusive overseer of government ethics. Its powers are mainly advisory (though its interpretation of some rules and statutes are effectively binding). Its capacity to coordinate the vast network of ethics business in the executive branch is limited. It has not even been able to serve as a repository for public records on ethics activities. The current director opposed the proposal (part of the Executive Branch Reform Act of 2007) to make the OGE a clearinghouse for information on lobbying contacts and to require that the information be made available to the public in a searchable computerized database. ${ }^{17}$

Obama's proposals would go some way toward strengthening the OGE, though (understandably for a document of this kind) they leave many questions unanswered. Before the OGE can enforce much of anything, it must be given some real enforcement powers. One proposal in the agenda is to give the OGE "strong enforcement authority with the ability to make binding regulations." Would this authority include the responsibility to impose consistent standards across all agencies for ethics training and the granting of waivers for conflict of interest laws? Currently, the ethics officials in each agency have considerable discretion to grant waivers, and evidently they deny very few requests. ${ }^{18}$ The OGE should have the authority necessary to make the practices uniform with due allowance for the special circumstances of the agencies.

Authority over training is especially important because the educational mission of the OGE should receive greater emphasis. Education is more important than punishment in the enforcement of ethics in a democracy in which a basic assumption should be that most officials want to serve the public interest. With greater uniformity and more robust education, it should also be possible to simplify significantly the rules and procedures for compliance-a much needed change that many officials would welcome. The change could also enable the

\footnotetext{
${ }^{17}$ Letter from Robert Cusik to Henry Waxman, U.S. Office of Government Ethics, February 23, 2007. Although Cusik raises some serious practical concerns, nearly all could be addressed by modifying the legislation, or by proposing alternative procedures for achieving the goals he says he agrees with. The letter offers no constructive suggestions along these lines. The director, appointed for a term lasting until 2011, was nominated by the then Senate majority leader Mitch McConnell.

18 "Testimony of Craig Holman Before the House Committee on Oversight and Government Reform, On the Subject of the Executive Branch Reform Act of 2007," Public Citizen, February 13, 2007.
} 
OGE to serve more effectively as the public repository for all ethics policies, reports, rules and such (even those that fall outside its own authority).

Should the OGE authority include subpoena power (which is now lacking) and authority to initiate prosecutions (which is now exclusively lodged in the Justice Department)? Granting the former is probably desirable, the latter doubtful. However, the OGE should be able to conduct investigations and impose civil sanctions necessary to secure cooperation. The investigations should be focused more on gathering information for changes in policy and procedures than on disciplining individuals.

Obama's other proposals to enforce executive branch ethics, many of which closely track the Executive Reform Act, represent sensible improvements. They include: closer cooperation with inspectors general, greater accessibility of public records containing information relevant to executive ethics, and new requirements to report all oral and in-person "lobbying contacts" between registered lobbyists and political appointees. Making information of this kind available in a publicly searchable database would better serve the purposes of ethics regulation. Officials would have a further incentive to avoid questionable conflicts and to file accurate and complete reports, and citizens would have greater assurance that they could discover any ethics problems that might exist. Even if few citizens ever seized the opportunity, its availability could enhance public confidence.

At present, the only way to see most conflict of interest disclosures and other similar information is by filing a freedom of information request with each individual agency. The OGE should have a website that makes available at least the public records it already collects on prior employment, individual financial statements, conflict of interest waivers and the office's own enforcement actions. In enforcing executive branch ethics, the broader objectives of consistency and transparency are easily lost sight of in the inevitable concern with details. Consistency is important for ensuring fairness to officials, and both consistency and transparency are essential for creating and sustaining trust in government. The OGE cannot serve as the ethics czar for the whole government, but it can, if given more specific and more potent authority, serve as an ethics counselor to the executive branch, and as an ethics enforcer when its counsel is ignored.

\section{"Shine the Light..."}

One of the most prominent themes of the Obama agenda is disclosure. It is as if the administration is prepared to constitutionalize Brandeis's aphorism, "Sunlight is the best disinfectant, electric light the best policeman." In addition to the database on lobbying contacts (broadened to include members of Congress and staff), the proposals include conducting all legislative sessions in public (including committee mark-ups and conference committees), creating a "contracts 
and influence" database (reporting what federal contractors spend on lobbying, the terms of the contracts, and whether they are fulfilled), setting up a searchable database that records tax breaks and earmarks for individual corporations, requiring a five-day public comment period before the president signs any nonemergency bill, giving advance notice of earmarks (with the name of the sponsor and a written justification), disclosing all communications between White House Staff and outsiders on any regulatory matters (no more Cheney-style task forces), guaranteeing timely release of presidential records, and requiring agency heads and cabinet officers regularly to conduct more business in public and periodically to hold town hall meetings with internet access.

As important as transparency is, it will probably need to be limited not only for the reasons its proponents acknowledge (to protect national security, law enforcement, and personal privacy), but also to facilitate the political compromises and bipartisanship that Obama hopes to achieve. Political science and political sense remind us that politicians are more likely to make concessions and find common ground in negotiations conducted under the cover of privacy than in the glare of publicity. The challenge is how to strike a balance between the confidentiality that compromise often needs and the exposure that accountability usually requires.

The demand for transparency may have to be modified in other ways as well. The requirements for financial disclosure, especially the dreaded 278 form, have become unnecessarily complicated. What is requested is no longer sufficiently attuned to the purposes of ethics regulation. Detailed information is required about holdings that could not possibly influence any official's decisions. Elaborate rules are enforced with no sensitivity to the radical changes in the nature of financial instruments in recent years. The OGE itself has recommended some improvements, but Congress has not yet acted. ${ }^{19}$ In the meantime, far too much time is spent on financial disclosure, and too little on exposure of other sources of conflict, such as the contacts officials have with campaign contributors and prospective employers.

Disclosure of financial and other information relevant to conflicts of interest is for several reasons necessary but not sufficient. First, what is disclosed is generally not used effectively. Stories on the financial conflicts are rarely presented in a way that help citizens make balanced judgments about the ethics of how decisions are made. The media are more interested in the sensational cases, especially those that focus on individual transgressions and criminal investigations, and less attentive to institutional patterns and historical trends. Second, disclosure gives officials themselves a false sense of ethical confidence.

\footnotetext{
${ }^{19}$ Office of Government Ethics, "Report to Congress: Evaluating the Financial Disclosure Process for Employees of the Executive Branch, and Recommending Improvements to It," March 2005.
} 
If they have disclosed their conflicts, they come to believe that they have met their ethical responsibilities, and do not have to take any further steps to deal with other pressures that are bound to arise. Their ethical duty is fulfilled by filling out their 278s. Social scientists have found that disclosure can also "increase the bias in advice because it leads advisers to feel morally licensed and strategically encouraged to exaggerate their advice even further. ${ }^{, 20}$ Third, disclosure by itself can be counter-productive. Disclosing a conflict of interest without offering any way of dealing with it merely reinforces citizens' distrust of officials. Disclosure alone can further undermine confidence in government.

It is a good general rule, then, that there should be no disclosure requirement without stipulating that someone should be charged with doing something with what is disclosed. There are two general methods for dealing with what is disclosed. The most common is to create a body with authority to require the elimination of the conflict (through such measures as recusal and divestiture). The less familiar method is to create a body with the capacity to interpret, for a wider audience, the significance of conflicts. ${ }^{21}$ The interpretations would focus more on institutional patterns and broad trends than individual cases and particular abuses. This could give ethical scrutiny a life after disclosure.

\section{Extending and Coordinating Ethics}

Obama's agenda reaches beyond the executive branch to Congress. In addition to calling for tougher lobbying rules, more publicity about earmarks, and more open congressional sessions, the president favors an independent body to oversee and enforce congressional ethics. ${ }^{22}$ He was one of the few members to go on record early in support of such a body. In the final months of the 110th Congress, the House established the Congressional Office of Ethics, a significant institutional breakthrough, even if the first individuals appointed to it are almost exclusively former members. The Senate has so far resisted creating any such institution. Obama's support could help, though this is one of those reforms that unites both parties against the public. Incumbents have a common interest in making sure ethics charges are handled by the devils they know, even colleagues on the other side of the aisle, rather than by the good government redeemers they suspect.

\footnotetext{
${ }^{20}$ Daylian M. Cain, George Loewenstein, and Don A. Moore, "The Dirt on Coming Clean: Perverse Effects of Disclosing Conflicts of Interest," Journal of Legal Studies 34 (January 2005), pp. $1-25$.

${ }_{21}$ For some suggestions along these lines (applied more broadly), see Archon Fung, Mary Graham, and David Weil, Full Disclosure: The Perils and Promise of Transparency (Cambridge, England: Cambridge University Press, 2007).

${ }^{22}$ For a discussion of such an institution, see Dennis F. Thompson, Ethics in Congress: From Individual to Institutional Ethics (Washington, DC: Brookings Institution Press, 1995).
} 
More important, though no less difficult, is an issue that is conspicuously absent from the ethics agenda Obama posted: campaign finance reform. Having opted out of public financing, justifiably contending that it is broken, Obama still has an obligation (one he acknowledged during his campaign) to try to reform the system. Campaign contributors who expect and receive privileged access are no less a threat to the democratic process than are lobbyists. They may be even more sinister because their influence is harder to detect. The influence is pervasive, spreading from Congress to the executive branch and into state and local government. There is of course no easy solution. That a good-government advocate as committed as Obama has seemed to move away from this issue is further confirmation of its difficulty.

But even if there is no easy solution, there is good reason to keep reform on the agenda, and to keep it in mind as other reforms are considered and implemented. Reforms in executive ethics are too rarely considered together with reforms in campaign ethics, even though the two obviously interact in many ways. Some of the most serious problems in recent years have resulted from failure to deal with the intrusion of fundraising activities into the business of governing. An important recent book on government ethics, by a former Bush White House counsel, argues that the goals of executive branch ethics cannot be achieved without stronger regulation of campaign practices. Among the most troublesome are the role of lobbyists in campaign fundraising and the intermingling of campaign activity and government business in the agencies and the White House. $^{23}$

The need for coordinated reform can be further brought out by noticing several consequences of the disjointed ethics regime that currently exists. First, in the absence of standardization in requests for information, officials are required to fill out multiple forms that ask similar questions but require slightly different answers. The requirement not only unnecessarily burdens the officials but also produces inconsistent and less useful sets of data. Accountability is thereby impaired. Reforms that do not take into account what is already required may exacerbate this problem. For example, lobbyists must report contacts under the Lobbying Disclosure Act, while under the proposed Executive Reform bill, officials would also be required to report contacts with some of the same lobbyists, but the information the officials and the lobbyists are required to report differs for no apparent reason.

Second, in the absence of a central repository for information, the disclosures, enforcement actions, and records of similar activities cannot be used effectively. Even officials charged with overseeing ethics practices and policies

\footnotetext{
${ }^{23}$ Richard W. Painter, Getting the Government America Deserves: How Ethics Reform Can Make a Difference (Oxford University Press, 2009), pp. 25-26, 245-53, 256-58.
} 
find it difficult to evaluate how the policies and procedures are working. Third, in the absence of coordinated communication, ethics officials cannot easily learn about successes and failures in other agencies and branches. They cannot readily benefit from "best practices" originated not only in other parts of the federal government, but also in the states, some of which are more advanced in ethics regulation than the federal government. ${ }^{24}$

Finally, without coordinated reform, a well-intentioned change in one practice may have unintended effects on other practices, undermining the original purpose. For example, if rules regulating lobbying contacts and revolving door practices are strengthened in government agencies, lobbyists may simply devote more resources to campaign committees and fundraising. Just as "money, like water, will always find an outlet," so influence, blocked at one opening, will find another. ${ }^{25}$ The aim of course should not be to try to stop the flow of influence, but to recognize that efforts to regulate it require attention to all of its potential points of entry.

With such an ambitious agenda for reform, we might expect that the Obama administration would include an equally ambitious instrument to coordinate these efforts. Reaching across two branches of government, and probing into core processes of decision making, the reform agenda obviously cannot be accomplished all at once. It will require sustained attention for many years just to implement some of the reforms, continued oversight to make sure they are working as intended, and an institutional capacity to promote further changes as needed.

Existing agencies and offices should continue to play an important role, but they cannot serve this comprehensive function. Even if the OGE is strengthened as Obama proposes, its independence, an advantage for administering ethics rules, is a handicap for formulating and promoting the president's ethics policy. Furthermore, its jurisdiction is limited to the executive branch, and more concerned with conflict of interest rules than with other parts of Obama's agenda, such as the transparency initiatives. The work of the Office of Personnel Management and Office of Management and Budget is certainly relevant to ethics regulation, but both are properly focused on other major challenges and cannot be expected to give ethics policy high priority. The OGE was created in part because the OPM was not thought to be an appropriate body to continue administering government ethics.

Attorneys in the Office of White House Counsel generally handles ethics matters for the president's staff and screens potential appointees for ethics

\footnotetext{
${ }^{24}$ For a study of ethics reform in state legislatures, see Beth A. Rosenson, The Shadowlands of Conduct: Ethics and State Politics (Washington: George Washington University Press, 2005).

${ }^{25}$ McConnell v. FEC 540 U.S. 93 (2003).
} 
problems. That Office has also usually been the principal source of advice on ethics policy for the president. But most of this advice concerns individual cases. Providing assistance in filling out the forms for appointees and the annual forms for all senior staff is a major task in itself. Moreover, even the policy advice, naturally reflecting the perspective of lawyers, is focused on what the law requires. Wise lawyers are not legalistic in a narrow sense and are more than capable of taking a broad view of institutional reform. But the ethics task is too wide-ranging to be left to any one kind of expertise and experience. Ethics reform in the form that the Obama agenda envisions it involves not only rules and regulations, but also the democratic process as a whole. It is nothing less than a program to put the principles of political ethics into practice. The task requires the contributions of political scientists, political philosophers, ethicists, and organizational behavior theorists, among others.

It might be thought that the breadth of the task calls for a national commission. For a contentious problem that is well-defined and limited in scope, commissions can be valuable. But because they usually require bipartisanship and representation of diverse groups and interests, commissions are not effective devices for providing specific advice to the president or reviewing his policies on an ongoing basis. Ethics reform is not a one-time initiative. The president needs to have the capacity to shape policies before they are finally proposed, and to control them once implemented. Commissions on Social Security and on the response to 9-11 were appropriate, but they were no substitute for the Council of Economic Advisers, the National Economic Council, or the National Security Council.

For political ethics, a single-enforcer system for the government as a whole is neither feasible nor desirable. But a single-coordinator system is. To carry out the wide-ranging agenda the president has proposed, he needs his own advisers to make recommendations, oversee their implementation, and conduct periodic reviews. There are White House offices for policy on science and technology, AIDS, health care, drug control, privacy and civil liberties, urban affairs, energy, and climate change. No less than these-indeed no less than economic and national security policy-ethics policy needs White House attention. A body devoted to ethics policy - call it the Council of Ethics Advisers-should have a place in the Executive Office of the President.

The Council would advise the president and his staff on the broad range of ethics issues. The Council would normally not deal with individual cases but would concentrate on general policies. Specifically, the Council would review current procedures and policies, examine the effectiveness of enforcement, report on trends and patterns in compliance and violations, explore best practices in the states and other countries, and provide opinions on relevant congressional legislation. It would make recommendations to the president for new policies and procedures and try to ensure that they are consistent across the government 
insofar as reasonable, taking into account the different circumstances of various agencies and branches.

Such a Council would be modeled on the Council of Economic Advisers, a group of three economists supported by a professional staff that provides "the President with objective economic analysis and advice on the development and implementation of a wide range of domestic and international economic policy issues." 26 The members and the staff of this Council come mostly from universities and research institutes. The Ethics Council staff would no doubt need some Washington lawyers and others with experience in the administration of ethics rules, but like the Council of Economic Advisers, it would also draw on talent in the universities and research institutions. It would seek to provide independent and relatively objective advice to the president. These observations of a former chair of the Council of Economic Advisers would apply equally well to an Ethics Council:

The academic nature of the staff and most members distinguishes the [the Council] from other government agencies. It generally assures a higher level of technical economic sophistication and of familiarity with current developments in economic thinking. Members and staff also use their strong links in the academic community to obtain advice on technical issues throughout their time in Washington. There is of course a price to be paid for this reliance on academic economists, especially at the staff level. They often come to the [Council] without the institutional knowledge of some of the issues with which they will deal and without any experience in the bureaucratic process of decision-making. My experience however was that most of the senior staff economists learned quite quickly to be effective participants, and made an important contribution to the policy debates because of their ability to apply economic analysis to the issues being discussed, and to develop new economic proposals that had not occurred to non-economist participants from the agencies. ${ }^{27}$

There would be some significant differences in the missions of the two councils. The Council of Economic Advisers is supposed to provide "objective economic advice." Although such advice is usually based on widely accepted views in the economics discipline, it is properly partisan or ideological in the sense that it supports the president's policy perspective (greater or less reliance on the market, for example). The Ethics Council does not need to be so committed to a partisan program. Ethics policies are to some extent partisan in the sense that they reflect a distinctive conception of democratic process, which may be more associated with one party than another. But they are not partisan in the sense of

\footnotetext{
${ }^{26}$ Council on Economic Advisers, http://www.whitehouse.gov/administration/ eop/cea/.

${ }^{27}$ Martin Feldstein, "The Council of Economic Advisers and Economic Advising in the United States," The Economic Journal 102: 414 (September 1992), p. 1223.
} 
favoring the general policies of one party rather than the other. For that reason, the ethics recommendations can be formulated with an eye toward continuity and should be expected to be more enduring.

Another difference comes from the fact that the ethics regime is relatively new, and partly for that reason much more disjointed and uncoordinated even than economic policy. The Ethics Council would first need to identify inconsistencies throughout the government before trying to develop more coherent policies. It would have to make a case for consistency in a regime that seems to have made flexibility its first principle. Finally, the Ethics Council would be more interdisciplinary. It could include members and staff from the several social sciences, philosophy, law, organizational behavior - and perhaps even economics. If its agenda were broadened to include bioethics and research ethics, physicians and public health experts would also be needed.

\section{Conclusion}

Obama's ethics agenda represents change that ethicists can believe in. More importantly, it proposes change that citizens who care about the health of the democratic process can believe in. Obama promises to enforce tougher standards than those observed in the previous administration and tougher in many respects than any in U.S. history. Moreover, his ethics agenda is not limited to the usual suspects - conflicts of interest, revolving doors and improper gifts - but seeks to capture a whole gang of practices that threaten the integrity of the democratic process, most notably the enemies of transparency and accountability. It is refreshingly focused more on institutional than individual ethics. Obama recognizes that transparent and accountable government is necessary to sustain public confidence, which is a primary aim of political ethics in a democracy. Yet his broad agenda is not accompanied by any proposals for the comparably broad process that is required for carrying it forward. The deficiencies of the current ethics regime cannot be remedied by any agency acting alone, and the Obama ethics agenda cannot be advanced without sustained planning and coordination from the White House. The ethics buck stops - and starts - there. 


\section{References}

Daylian M. Cain, George Loewenstein, and Don A. Moore, "The Dirt on Coming Clean: Perverse Effects of Disclosing Conflicts of Interest," Journal of Legal Studies 34 (2005), 1-25.

Robert Cusik, "Letter to Henry Waxman," U.S. Office of Government Ethics (February 23, 2007). http://www.nrlc.org/FreeSpeech/OGEcommentsHR984.pdf.

Martin Feldstein, "The Council of Economic Advisers and Economic Advising in the United States," Economic Journal 102 (1992), pp. 1223-34.

Archon Fung, Mary Graham, and David Weil, Full Disclosure: The Perils and Promise of Transparency (Cambridge, England: Cambridge University Press, 2007).

Craig Holman, "Testimony Before the House Committee on Oversight and Government Reform, On the Subject of the Executive Branch Reform Act of 2007," (Washington, DC: Public Citizen, February 13, 2007).

http://oversight.house.gov/documents/ 20070213122838-84277.pdf.

G. Calvin Mackenzie, Scandal Proof: Do Ethics Laws Make Government Ethical? (Washington, DC: Brookings Institution Press, 2002).

McConnell v. FEC 540 U.S. 93 (2003).

Robin M. Nazzaro, "Testimony before the Committee on Natural Resources, House of Representatives, Endangered Species Act Decision Making," U.S. Government Accountability Office (May 21, 2008).

http://www.gao.gov/new.items/d08688t.pdf.

Obama-Biden Plan, “Agenda: Ethics,” http://change.gov/agenda/ethics_agenda/. 
Office of Government Ethics, "Report to Congress: Evaluating the Financial Disclosure Process for Employees of the Executive Branch, and Recommending Improvements to It" (March 2005). http://www.iecjournal.org/ iec/files/rpogc_fin_dis_03_05.pdf.

New York Times Editorial Board, "The President Orders Transparency," New York Times (January 23, 2009).

Richard W. Painter, Getting the Government America Deserves: How Ethics Reform Can Make a Difference, (New York: Oxford University Press, 2009).

Beth A. Rosenson, The Shadowlands of Conduct: Ethics and State Politics, (Washington, DC: George Washington University Press, 2005).

Barbara L. Schwemle, "Federal Personnel: Conversion of Employees from Appointed (Noncareer) Positions to Career Positions in the Executive Branch," (Washington, DC: Congressional Research Service, October 14, 2008). http://fas.org/sgp/crs/ misc/RL34706.pdf

Dennis F. Thompson, Ethics in Congress: From Individual to Institutional Ethics. (Washington, DC: Brookings Institution Press, 1995).

Gregory S. Walden, On Best Behavior: The Clinton Administration and Ethics in Government, (Indianapolis, IN: Hudson Institute, 1996). 